\title{
The Canadian Law Review Experience: INTRODUCTION TO THE SYMPOSIUM
}

\section{BRUCE ZIFF*}

Over the years there have been a number of retrospectives on the American law review.' Legal academics in the United States seem endlessly intrigued by the subject. Articles appear on the history of law reviews, their many failings, or their precarious future. Tabs are kept on the most-cited review articles. ${ }^{2}$ In contrast, although law journals have been a fixture on the Canadian scene for about 150 years, "[t]here is almost a complete absence of published scholarship about scholarly legal periodicals in Canada."4 Those involved in Canadian law reviews have gone about their business in a largely unselfconscious fashion.

It cannot be that the Canadian law review is an unworthy object of inquiry. At bottom, law journals provide an effective vehicle for commentators to reach audiences both within Canada and abroad. They are useful soap boxes; yet they are more than that. In Canada journals have served as a training ground for law students and a proving ground for academics. In the eyes of some, the law review acts as a self-appointed final court of appeal; the unofficial Judicial Committee of the Privy Council. In addition, law reviews are deeply implicated in the quest for academic cachet. Law schools boast of the journals they produce. Publications in law reviews count in hiring, tenure, and promotion decisions. Moreover, within the Canadian law review experience is an embedded history. The nature of law journals, their avowed missions, their contents, and so forth have altered over time. These developments are, in part, manifestations of the state of legal scholarship at any given time. Law reviews can thus be studied to learn something about developments in both Canadian law and scholarship.

Given the significance of legal journals in Canada, and the paucity of writing on the subject, it may be an appropriate time to take stock. With this in mind, a panel was organized for the May 2000 meetings of the Canadian Association of Law Teachers (CALT) at the University of Alberta. Five papers were presented at the session. ${ }^{5}$ The present collection - the contents of which are outlined below - developed out of those presentations.

Donna Greschner's lead article, "Law Reviews as Cultural Narrative," outlines the historical development of law reviews in Canada. She argues that the Canadian perspective

Professor of Law. Chair of the Alberta Law Review Faculty Advisory Committee and Consulting Editor for the Symposium.

See the Select Bibliography, infra at 690 .

See. e.g.. F.R. Shapiro. "The Most-Cited Law Review Articles Revisited" (1996) 71 Chi.-Kent L. Rev. 751.

B. Ryder. "The Past and Future of the Canadian Generalist Law Journal" (2001) 39 Alta. L. Rev. 625 at 627 , where it is noted that the Canada Law Journal first appeared in 1855.

Ibid. at 625 .

The five papers presented at the session were those by Professors Greschner. Hutchinson, Macdonald. Olsen, and Ryder. 
was at one time heavily laden with American influences. In time law reviews in both the common law jurisdictions and in Quebec began to assume unique attributes. The characteristics that emerged - including our boundless capacity to agonize over constitutional reform - reflect many of the defining features of Canada as a whole. It is Law Review as epitome.

Bruce Ryder's article, "The Past and Future of Canadian Generalist Law Journals," also charts the development of law reviews in Canada. His account concentrates on the emergenceand proliferation of university-based law journals. The growth of generalist law reviews continued apace following the Second World War, then stopped, suddenly, in 1973. Since then we have seen the arrival of a variety of specialist periodicals, including some, just a few, which adopt interdisciplinary perspectives. Professor Ryder identifies the institutional factors that prompted the shift from generalist to specialist journals, and he reflects on the relative merits of these two forms.

In the spring of 2000 a letter written by Beverley McLachlin, the newly appointed Chief Justice of the Supreme Court of Canada, arrived at the Faculty of Law of the University of Alberta. The missive, which had been sent to law schools across the country, stated:

It has recently come to my attention that some law professors have been sending unsolicited (and in some cases, unpublished) manuscripts to our law clerks relating to cases pending before this court. In some instances, the sender has specifically expressed the hope that the contents of the manuscript will influence the thinking of the court. Procedural fairness, of course, precludes us from receiving any materials that have not been circulated to the parties.

No one should be in a position to make secret representations to the court or become, in effect. an unseen intervener in the case. Accordingly, our policy is to return such materials unread."

This somewhat famous letter - it was reported in the press several months later ${ }^{7}-$ hints at a certain complex dynamic between scholarly writing and judicial decisionmaking. What is the appropriate place of legal writing in the judicial process? Two papers take up this question. In "Far-Cited," the Honourable Mr. Justice Jean Côté of the Alberta Court of Appeal provides an insider's perspective. (See also the Right Honourable Madam Chief Justice McLachlin's presentation on the virtues and vices of legal writing, published in this issue. ${ }^{8}$ ) Justice Côté canvasses the questions of when and how law review articles (and other forms of scholarship) are invoked in judicial decision-making. Suggesting that there are at least eight main reasons why such works might find their way into judgments, he focuses on one critical issue: in those instances in which a court has a fairly free hand in resolving a dispute, to what types of scholarship should it turn? Stated another way, given the wealth of material at hand, are there reliable indicia to guide a court in seeking

6 Letter from B. McLachlin to the University of Alberta, Faculty of Law (28 March 2000).

' See, e.g., L. Chwialkowska, "Chief Justice warns scholars not to sway cases" Edmonton Journal (26 September 2000) A8. The story was first printed in the National Post. 
assistance from legal scholarship (apart, of course, from the cogency of a given argument)?

Professor Allan Hutchinson provides a very different perspective. His piece, "The Role of Judges in Legal Theory and the Role of Legal Theorists in Judging," is a response to a paper on legal scholarship and the courts written by the Honourable Mr. Justice Michel Bastarache of the Supreme Court of Canada and published in an earlier volume of the Review. ' (Ergo, Hutchinson's subtitle "Or,'Don't Let the Bastaraches Grind You Down.") Bastarache's conception of useful legal scholarship is challenged. Hutchinson is also critical of the penchant of those academics who aspire to produce work with the end of serving judicial needs and who measure academic merit through an accounting of judicial citations. He chalks up such a practice to insecurity and lack of a sense of selfworth. Scholars, he argues, owe their allegiance to the academy, not the courts. Hence, rather than serving as glorified law clerks, academics should engage in a completely different notion of "useful" jurisprudence; work that has critical bite and intrinsic value.

In Rod Macdonald's "Epistles to Apostles" the idea of utility is also taken up within the context of law reform. Macdonald argues if law reviews are to inform the work of law reform agencies, these journals must "renounce being 'useful' in the instrumental sense, to both lawyers and judges." 10 This is just one of the insights contained in this imaginative essay, which explores the lessons for scholarship and reform that may be gathered from biblical analogues. Organized around the Gospels of Matthew, Mark, Luke, and John, it is Professor Macdonald's thesis that each Gospel, in its own way, contains lessons about the aspirations of both law reviews and law reform commissions.

Bruce Ryder and Donna Greschner both refer to Canadian law reviews by reference to their American counterparts (as do I, above). At the Canadian law teachers' meeting in 2000, Frances Olsen of the U.C.L.A. School of Law was invited to provide an American point of view. Her paper, "The Role of Student-Run Law Journals in Opening North American Law" is designed as a panegyric. Given the many harsh criticisms of the student-run review, there is still room to sing its praises. Indeed, she argues that the supposed weaknesses of student-edited law journals can be understood as strengths. So, while student editors may be novices (and some may not be), they are at the same time open to fresh ideas about what counts as publishable scholarship. And while the large number of journals might suggest that the quality of some published material is questionable, the array of choice increases the likelihood that worthwhile writing will see the light of day, including articles that are unorthodox, even radical. And she endorses the pedagogical case for student-run reviews. This was, after all, the rationale for conferring the role of editing on law students in the first place.

The final word is given to Larissa Katz, who not too long ago served as an editor-inchief of the Alberta Law Review. She focuses on the dilemmas faced by those students

M. Bastarache, "The Role of Academics and Legal Theory in Judicial Decision-Making" (1999) 37 Alta. L. Rev. 739. The paper is based on an oral address to the students of the Law Faculty. University of Alberta (20 November 1998).

10

R. Macdonald, "Epistles to Apostles" (2001) 39 Alta. L. Rev. 668 at 676. 
who assume the stewardship of legal journals. Editors must of course rely on expert peer review. Nevertheless, she argues, editorial decision-making should not be delegated to the external reviewer. Nor should article selection be driven by perceptions (guesses) about the needs of an imagined audience. Instead, editors should develop a sense of mission and prefer those articles that fit within that vision. The fixing of a journal's raison d'être might be informed by the ways that scholarship - as opposed to, say, judicial decisions - can provide truly unique contributions to learning.

The articles presented here are designed to provide a retrospective; an appraisal of things past. What will the future bring?

One development seems to be in the offing. As Bruce Ryder notes, until recently there has never been a full-fledged association of Canadian law reviews. "Student editors come and go each year, which accounts both for the need for an association to provide continuity and coordination and the difficulty of establishing such a co-operative enterprise. Law review time is precious, and the pressures to produce the journal on time are unrelenting. Nonetheless, in early August 2001 a two-day meeting of Canadian student law reviews was convened in Saskatoon, Saskatchewan. Those in attendance ${ }^{12}$ resolved to establish the Canadian Association of Law Journals. Provisional arrangements have been made for this organization to meet again at Osgoode Hall in 2002.

The major challenge that the membership of such an association faces is obvious: helping to define the place of the law review in the digital age. In the last twenty years or so every element of the publication process has been transformed by new information technologies. Today every law journal has a web site (I would think); electronic index services now abound; many journals place full text versions of their articles online; some journals publish exclusively on the Internet. ${ }^{13}$

It does not, and will not, end there. Law reviews have not existed since time immemorial; nor is their place assured forever. Writers can now with relative ease post material on their own web pages, instantaneously making it available worldwide. One has the capacity to revise a paper at will and to display ongoing commentary from readers. That all being so, is there still a meaningful role for law journals? The answer may depend in part on the extent to which the traditional auxiliary functions of Canadian law reviews remain worthwhile. For instance, will it still be sensible to use law reviews (online or otherwise) as a means of vetting scholarship or as a site of legal education? Will the law review's more dubious use as a source of professional or institutional credibility and status enable it to endure? The answers remain uncertain. ${ }^{14}$

Supra note 3 at 636 . The only other attempt to form an association occurred back in 1959: ibid. There were representatives from U.B.C., Osgoode Hall, Saskatchewan, and Alberta.

See, e.g., The Estey Centre Journal of International Law and Trade Policy, online: Estey Centre Homepage <http://cafri.usask.ca/estey/about.htm> (date accessed: 23 August 2001).

For an example of what may be the shape of things to come, see B.J. Hibbitts, "Last Writes? Reassessing the Law Review in the Age of Cyberspace," online: Hibbitts Home <http://www.law.pitt. edu/hibbitts/lastrev.htm> (date accessed: 23 August 2001). See also "Special Issue: Who Needs Law Reviews? Legal Scholarship in the Age of Cyberspace" (1996) 30 Akron L. Rev. 173-323 and B.J. Hibbitts, "Yesterday Once More: Skeptics, Scribes and the Demise of Law Reviews," which is 
Many people have assisted in the preparation of this collection. It was mentioned above that the seeds for the symposium were planted during Congress 2000. With the help of Professor Annalise Acorn, then President of CALT, Marian Fluker and Larissa Katz, the editors-in-chief of the Alberla Law Review, developed the idea for a panel. They were assisted by Elena Sacluti and Stella Varvis of the editorial board. Ms. Varvis also served as the moderator. Anne Côté and Paul Eastwood, the incoming editors-in-chief, took over stewardship of the project. The current co-editors, Alana Harding and Deborah Szatylo brought it to completion. Tracie Scott, a third-year law student at the University of Alberta, prepared the select bibliography.

contained in the Hibbitts web site. It is notorious that readership for most law review articles is quite small. It is therefore remarkable that between March 6, 1997, and August 23, 2001. a total of 7,620 visits were made to the web page at which "Yesterday Once More" is posted. 